\title{
Dorota Siemińska*
}

https://doi.org/10.18778/8220-375-2.07

\section{Koreańska Fala jako główne narzędzie soft power Korei Południowej}

\begin{abstract}
Korean Wave as the main soft power tool of South Korea

The Korean Wave is a very important element of South Korea's soft power and has been bringing a lot of benefits to the country for many years. Over the past decade, it has evolved into a global sensation and gradually the whole world is becoming interested in it. This is a phenomenon worth investigating due to the wide range of aspects in which it applies. Politicians around the world recognize it as a powerful phenomenon and it appears in the speeches of not only the presidents of South Korea, but also foreign presidents in relation to the Korean state. In addition to politics, the Korean Wave also helps to increase the level of the economy and influences social views. The main purpose of this work was to show the impact of the Korean Wave and how the government uses it to build the image of the country. The methodology used to study this topic is mainly qualitative and quantitative data. The author also uses a comparative method, discussing, for example, the views of different countries on the Korean Wave and its impact on mutual relations. The work answers the questions: how the Korean Wave has changed over the past twenty years; how the head of state connects official meetings with Korean culture; how it affects relations with specific countries. The thesis was adopted: The Korean Wave has a positive impact on building the image of the state, and the Korean government has noticed its potential and skilfully uses it. As a result of the analysis of available literature and Internet data, this thesis has been confirmed.
\end{abstract}

Keywords: soft power, Korean Wave, culture, politics

Słowa kluczowe: soft power, Koreańska Fala, kultura, polityka

\section{Wprowadzenie}

Kultura jest obecna na każdym kroku i w każdym aspekcie naszego życia. Wiele krajów posiada własną kulturę, którą pielęgnuje poprzez podtrzymywanie tradycji. Niektóre z nich rodzą się poprzez połączenie istniejących już wcześniej z zupełnie nowymi elementami. Koncept kultury jest ściśle powiązany

"Absolwentka studiów I stopnia, kierunek stosunki międzynarodowe, specjalność Asian Studies na Wydziale Studiów Międzynarodowych i Politologicznych Uniwersytetu Łódzkiego, studentka studiów II stopnia, kierunek stosunki międzynarodowe, specjalność orientalna WSMiP UŁ; e-mail: dorota.sieminska@unilodz.eu. 
z kulturą popularną, która zapewnia rozrywkę i daje początek wielu ciekawym pasjom. Niektóre z nich są rozpoznawalne na całym świecie i mają znaczący wpływ nie tylko na społeczeństwo, ale także na strefy biznesu i polityki. Tak jest w przypadku kultury popularnej Korei Południowej, szerzej znanej pod nazwą Koreańskiej Fali lub Hallyu, w ostatnich latach rozwijającej się niezwykle dynamicznie i wciąż zdobywającej tłumy nowych odbiorców.

Koreańska Fala była początkowo popularna tylko w Azji Wschodniej, obecnie jej wpływy sięgają każdego zakątka świata. Związany z nią przemysł prosperuje bardzo dobrze i przynosi duży dochód koreańskiej gospodarce. Ludzie na całym świecie lubią koreańską muzykę, filmy, kosmetyki, jedzenie i wiele innych. Wzrosła liczba osób podróżujących do Korei Południowej, tak jak zainteresowanie językiem koreańskim i tradycjami tego kraju. Będąc tak potężnym zjawiskiem, Koreańska Fala stała się kluczowym elementem południowokoreańskiego soft power, które opiera się na zdolności państwa do zdobywania wpływów dzięki atrakcyjności własnej kultury i polityki. Rząd Korei Południowej oficjalnie promuje i finansuje Koreańską Falę, a inne kraje marzą o odniesieniu takiego samego sukcesu. Celem niniejszego artykułu jest ukazanie wpływów Hallyu oraz tego, jak rząd Korei Południowej wykorzystuje jej potencjał w sferze politycznej.

Aby lepiej zrozumieć fenomen, jakim stała się Koreańska Fala, powinniśmy cofnąc się do jej początków. Wywodzi się ona z Korei Południowej i zyskała rozpoznawalność dzięki erze Internetu i social mediów. Termin ten, w języku koreańskim funkcjonujący jako Hallyu, został stworzony w 1999 roku przez chińskich dziennikarzy, którzy byli zafascynowani gwałtownym wzrostem popularności południowokoreańskiej kultury i rozrywki w Chinach ${ }^{1}$. Na Koreańską Falę składa się każdy aspekt kultury Korei, od muzyki (k-popu) i dram (seriali telewizyjnych) po język, kuchnię i tradycję2. Światowy zasięg doprowadził do używania jej jako narzędzia soft power, wpłynął na społeczeństwo i stworzył dochodowy biznes. Tak zwana Pierwsza Fala Hallyu, która trwała od 1997 do 2007 roku, skupiała się głównie na eksporcie programów telewizyjnych i filmów. Dla kontrastu, trwająca od 2008 roku do dziś, Druga Fala Hallyu kładzie nacisk na kreatywne treści i technologie cyfrowe 3 . Rząd Korei Południowej odgrywa znaczącą rolę w finansowaniu Hallyu i promuje Koreańską Falę jako oficjalną politykę mającą na celu poprawę ekonomii państwa. Rozpowszechnianie się zjawiska można porównać do japońskiej kultury popularnej w latach 2000., na przykład anime, gry i jedzenie. Era cyfrowa odgrywa

${ }^{1}$ S. Lee, The Korean Wave: The Seoul of Asia, „The Elon Journal of Undergraduate Research in Communications" 2011, Vol. 2, No. 1, s. 86.

${ }^{2}$ R. Lukmanda, Popular Culture through Globalization. The Power of Hallyu, https://www.academia. edu/9339896/Popular_Culture_through_Globalization_The_Power_of_Hallyu (dostęp: 1.12.2019).

${ }^{3}$ D. Jin, New Korean Wave: Transnational Cultural Power in the Age of Social Media, University of Illinois Press 2016, s. 8-9. 
kluczową rolę w odbiorze Hallyu, ponieważ jest ona konsumowana głównie poprzez Internet i social media ${ }^{4}$.

Koreańska Fala składa się z wielu elementów, zaś najbardziej znany jest k-pop. Ten gatunek muzyczny zaczął być popularny na wielką skalę w ostatniej dekadzie. Powstał z połączenia elementów zachodnich i kultury azjatyckiej i stanowi mieszankę innych gatunków, takich jak hip-hop, jazz, R\&B czy reggae ${ }^{5}$. Przełomem dla koreańskiego popu był występ grupy Seo Taiji and Boys w 1992 roku. Był to szok kulturowy dla Korei Południowej, ponieważ piosenka była silnie inspirowana amerykańskim hip-hopem. W latach 80. Południowi Koreańczycy byli zmuszani do słuchania patriotycznych utworów, takich jak Och, Republika Korei!, ponieważ jedynie treści zatwierdzone przez rząd były dopuszczane do emisji. Taka cenzura popkultury została zapoczątkowana przez ówczesnego dyktatora Park Chung-hee i utrzymywana przez wiele lat po jego śmierci w 1979 roku$^{6}$. Z powodu tak wielkich restrykcji różnorodność muzyki dostępnej dla mieszkańców kończyła się na balladach. Właśnie dlatego telewizyjny debiut Seo Taiji and Boys był nietypowy i pokazał, że rozwój kulturalny i otwartość na wpływy zewnętrzne stały się możliwe. Sam zespół został swego rodzaju symbolem, wyrażającym proces zmian nie tylko branży kulturowej, ale całego państwa ${ }^{7}$. Grupa została wybrana jako jedna z 50 postaci, które od 1945 roku znacząco wpłynęły na koreańskie społeczeństwo ${ }^{8}$.

W latach 60. XX wieku Korea Południowa była jednym z najbiedniejszych krajów, z 34. PKB na świecie (3,9 miliarda dolarów), a w 1996 roku, krótko po rozwiązaniu Seo Taiji and Boys, zajmowała 11. miejsce (598 miliardów dolarów). W 2017 roku posiadała już dochody rzędu półtora biliona dolarów rocznie i obecnie utrzymuje pozycję jednego z najbogatszych państw na świecie ${ }^{9}$. Koreański biznesmen i były artysta Lee Soo-man, zainspirowany sukcesem grupy Seo Taiji and Boys, wpadł na pomysł podboju świata poprzez muzykę. Znalazł niszę na rynku i zapoczątkował sprzedaż muzyki jako towaru kulturalnego. Na każdym kroku podkreślał, że jest ona produkowana właśnie w Korei. Kiedy w 1997 roku kraj został dotknięty przez Azjatycki Kryzys Finansowy, rząd Korei Południowej miał taki sam pomysł jak Lee Soo-man i przedstawiał kulturę jako towar eksportowy. W 1999 roku uchwalono ustawę poświęconą

${ }^{4}$ Y. Kuwahara, The Korean Wave: Korean Popular Culture in Global Context, Palgrave Macmillan 2014, s. 1.

${ }^{5}$ T.N. Laurie, Global Glam and Popular Music Style and Spectacle from the 1970s to the 2000s, New York 2016, s. 216-217.

${ }^{6}$ E. Klein, J. Posner, K-pop, Explained, Netflix, USA, 30.05.2018.

${ }^{7}$ Ibidem.

${ }^{8} \mathrm{D}$. Shim, Hybridity and the rise of Korean popular culture in Asia, ,Journal of Media, Culture \& Society" 2006, Vol. 28, No. 1, s. 36-37.

${ }^{9}$ World Bank, GDP (Current US\$) Korea, Rep, https://data.worldbank.org/indicator/NY.GDP. MKTP.CD?locations=KR (dostęp: 1.12.2019). 
wspieraniu sztuki i obiecano przeznaczać co najmniej jeden procent całego budżetu państwa na kulturę ${ }^{10}$.

Kluczowym momentem w prezentacji Koreańskiej Fali globalnej publiczności był rok 2012. Gdy artysta PSY (Park Jae-sang) wydał utwór o nazwie Gangnam Style, oczy świata zwrócily się w kierunku Korei. Jako pierwszy w historii film przełamał barierę miliarda wyświetleń na portalu YouTube i zapoznał wiele osób z koreańską kulturą popularną. Wcześniej mało kto spoza Korei Południowej wiedział o k-popie czy miał jakiekolwiek pojęcie na temat koreańskiej kultury. Piosenka nawiązuje do zamożnej koreańskiej dzielnicy Gangnam, często porównywanej do Midtown w Nowym Jorku lub Beverly Hills w Kalifornii. Dawniej były tam pola uprawne, a obecnie to centrum mody, symbol luksusowego życia i materializmu, generujący $7 \% \mathrm{PKB}^{11}$.

\section{Koreańska Fala jako soft power oraz działania rządu}

Korea Południowa w umiejętny sposób wykorzystuje swoją kulturę jako narzędzie soft power. Po raz pierwszy koncept ten przedstawił Joseph S. Nye w książce Bound to Lead: The Changing Nature of American Power, kiedy opisywał Stany Zjednoczone jako najpotężniejszy naród w dziedzinie atrakcyjności, poza posiadaniem ogromnych zasobów militarnych i statusu jednej z największych gospodarek na świecie ${ }^{12}$. Zdefiniował on siłę jako zdolność wywierania wpływu na działania innych i osiągania pożądanego rezultatu. Istnieją trzy rodzaje siły: twarda (hard power), miękka (soft power) oraz połączenie tych dwóch, zwana inteligentną (smart power). W kontekście hard power kontrola uzyskiwana jest poprzez groźby lub wymuszenia, natomiast soft power wykorzystuje przyciąganie uwagi i kierowanie współpracą w taki sposób, aby ludzie robili to, czego się od nich oczekuje ${ }^{13}$.

Jako pierwszy możliwość wykorzystania kultury koreańskiej jako narzędzia soft power zauważył Kim Gu, szósty i ostatni prezydent Rządu Tymczasowego Republiki Korei (1927, 1939-1948). Jego autobiografia Baekbeomilji (Dziennik Baekbeom), opublikowana po raz pierwszy w 1947 roku, jest niezwykle istotna dla koreańskich historyków, a rząd nadał jej status skarbu kultury. W książce tej Kim Gu podkreśla pragnienie narodu koreańskiego bycia siłą kulturalną, a nie militarną:

Chcę, aby nasz naród był najpiękniejszy na świecie. Nie mam na myśli najpotężniejszego narodu. Ponieważ odczułem ból związany z inwazją innego narodu, nie chcę, aby mój naród najechał innych. Wystarczy, że

${ }^{10}$ E. Klein, J. Posner, op. cit.

${ }^{11}$ N. Duran, OPPA GANGNAM STYLE PHENOMENON: Dance Craze, Images, and the Perception of the Philippine Audience, https://www.academia.edu/7590669/OPPA_GANGNAM_ STYLE_PHENOMENON_Dance_Craze_Images_and_the_Perception_of_the_Philippine_Audience (dostęp: 1.12.2019).

${ }^{12}$ J.S. Nye, Soft Power: The Means to Success in World Politics, New York 2004, s. XI.

${ }^{13}$ Ibidem, s. 68. 
nasze bogactwo wzbogaci nasze życie, wystarczy, że nasza siła jest w stanie zapobiec obcym najazdom. Jedyną rzeczą, której pragnę w nieskończonej ilości, jest siła szlachetnej kultury. Jest tak, ponieważ siła kultury zarówno nas cieszy, jak i daje szczęście innym ${ }^{14}$.

Pierwszym prezydentem, który oficjalnie wspomniał o fenomenie Hallyu był Kim Dae-jung. W przemówieniu na Trzeciej Konferencji Promowania Turystyki w 2001 roku $^{15}$ podkreślił on znaczenie rozwoju branży turystycznej i wkład kultury kraju we wzrost gospodarczy. Podczas Pierwszej Fali Hallyu rząd koreański wspierał przemysł kulturalny tylko pośrednio. Wraz z przejściem w Drugą Falę skupiono się na polityce kulturalnej, a rząd zaczął bezpośrednio i aktywnie wspierać oraz finansować ten fenomen. Pionierami tej zmiany byli prezydenci Lee Myung-bak i Park Geun-hye ${ }^{16}$.

Niedługo później zauważono, że odpowiednia organizacja światowych wydarzeń jest oznaką nowoczesności i niezwykle opłacalną reklamą dla kraju. Pierwszymi próbami przedstawienia państwa koreańskiego międzynarodowej publiczności były Letnie Igrzyska Olimpijskie w 1988 roku oraz Mistrzostwa Świata w Piłce Nożnej w 2002 roku. Te dwa wydarzenia były nie tylko wyjątkowymi okresami w historii tego kraju, ale także poważnymi projektami, w które była zaangażowana koreańska gospodarka i polityka. Kiedy jakieś państwo jest gospodarzem Igrzysk Olimpijskich, zyskuje ono szacunek i jest postrzegane jako ważny aktor na scenie międzynarodowej. Korea wykorzystała wydarzenia sportowe, aby stworzyć swój pozytywny wizerunek. Na poziomie krajowym nastąpiło skierowanie polityki w kierunku stosunków międzynarodowych z włączeniem kultury ${ }^{17}$.

Ministerstwo Spraw Zagranicznych Korei Południowej jest zaangażowane w globalną promocję Hallyu. Jednym z największych organizowanych przez nie wydarzeń jest coroczny K-Pop World Festival. To doskonała okazja dla fanów, aby zasmakować życia gwiazdy k-popu. Grupy taneczne i wokalne z całego świata przesyłają zgłoszenia, a następnie kilkoro szczęśliwców jest zapraszanych przez rząd, aby zaprezentować się w koreańskim mieście Changwon ${ }^{18}$.

W 2018 roku Republika Korei była gospodarzem Zimowych Igrzysk Olimpijskich w Pyeongchangu. Podczas tak ważnego wydarzenia rząd koreański po raz kolejny polegał na kulturze popularnej swojego kraju. Na ceremonii

${ }^{14}$ Kim Koo, https://en.wikipedia.org/wiki/Kim_Koo (dostęp: 1.12.2019).

${ }^{15}$ D. Jin, T. Kim, Cultural Policy in the Korean Wave: An Analysis of Cultural Diplomacy Embedded in Presidential Speeches, „International Journal of Communication” 2016, Vol. 10, s. 5522.

${ }^{16}$ D. Jin, op. cit., s. 67.

${ }^{17} \mathrm{~J}$. Kim, Rethinking Media Flow under Globalisation: Rising Korean Wave and Korean TV and Film Policy since 1980s, Centre for Cultural Policy Studies of University of Warwick, maj 2007, s. 150-152.

${ }^{18}$ Ministry of Foreign Affairs in South Korea, Foreign Ministry to Host a K-Pop Show as Part of Hallyu Diplomacy, 3.05.2012, https://www.mofa.go.kr/eng/brd/m_5676/view.do?seq=311119\&s-

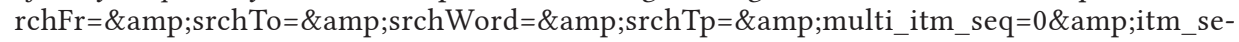
q_1=0\&amp;itm_seq_2=0\&amp;company_cd $=\& a m p ; c o m p a n y \_n m=\& p a g e=404 \&$ titleNm $=$ (dostęp: 1.12.2019). 
zamknięcia wystąpiły koreańskie gwiazdy rozpoznawalne na całym świecie - wokalistka CL z zespołu 2NE1 oraz grupa EXO. Transmisja wydarzenia przyciągnęła nie tylko rzesze fanów, ale sprawiła również, że wiele osób, które miały styczność z koreańską popkulturą, zaczęło zgłębiać temat. Kolejny raz działania rządu, wspomagane działaniami mediów, przyczyniły się do efektywnego soft power ${ }^{19}$. Po sukcesie Zimowych Igrzysk zespół EXO został nagrodzony przez Korea Minting, Security Printing \& ID Card Operation Corporation (KOMSCO - koreańska korporacja rządowa odpowiedzialna za emisję koreańskiej waluty won oraz innych ważnych dokumentów i kart, takich jak dowody osobiste) specjalnymi medalami. To jedyna grupa k-popowa, która otrzymała tego rodzaju prestiżową nagrodę z rąk rządu za gigantyczny wkład w globalną promocję kultury koreańskiej ${ }^{20}$.

\section{Koreańska Fala w działaniach głowy państwa}

Od kilku lat czołowi koreańscy politycy otwarcie wprowadzają elementy Koreańskiej Fali do swoich kampanii prezydenckich. Gdy w 2012 roku kandydaci Park Geun-hye i Moon Jae-in walczyli o władzę, koreańska popkultura przyszła im na ratunek, ponieważ oboje wykorzystali piosenki k-popowe jako motywy przewodnie swoich kampanii. Wraz z rosnącą popularnością Hallyu wśród młodych ludzi politycy coraz chętniej wspierają ten nowy gatunek muzyki i stopniowo wprowadzają go do swojej działalności ${ }^{21}$.

Podczas sprawowania swojego urzędu prezydent Park Geun-hye była świadoma rosnącej popularności Koreańskiej Fali, wspierała ją i promowała. Zwracając się do narodu w przemówieniu inauguracyjnym, podkreśliła ogromne znaczenie kultury w funkcjonowaniu państwa: „W XXI wieku kultura jest potęgą. To era, w której wyobraźnia staje się twórczą treścią. Na całym świecie Koreańska Fala jest przyjmowana z wielką sympatią, która nie tylko wywołuje szczęście i radość, ale także wzbudza dumę u wszystkich Koreańczyków”22. Jej wizyty dyplomatyczne w wielu krajach były często związane z wydarzeniami kulturalnymi. Zawsze próbowała przekazywać koreańskie tradycje i kulturę. Podkreślała ogromne znaczenie wymiany kulturowej w budowaniu długoterminowych relacji ${ }^{23}$. Na przykład, w grudniu 2015 roku w Pradze, podczas

\footnotetext{
${ }^{19} \mathrm{M}$. Belam, EXO: K-pop boyband thrills Winter Olympics closing ceremony, „The Guardian”, 24.02.2018, https://www.theguardian.com/sport/2018/feb/24/who-are-exo-the-boyband-aboutto-thrill-the-winter-olympics-south-korea-k-pop/ (dostęp: 1.12.2019).

${ }^{20}$ Y. Magcamit, EXO Becomes First K-Pop Act to Be Awarded Own Commemorative Medals, „Hello Kpop”, 18.04.2018, https://www.hellokpop.com/news/exo-receives-komsco-official-commemorative-medals/ (dostęp: 1.12.2019).

${ }^{21}$ I. Oh, H. Lee, K-pop in Korea: How the Pop Music Industry is Changing a Post-developmental Society, „Cross-Currents: East Asian History and Culture Review” 2013, No. 9, s. 116-118.

${ }^{22}$ Yonhap News Agency, Full text of Park's inauguration speech, 25.02.2013, https://en.yna. co.kr/view/AEN20130225001500315 (dostęp: 1.12.2019).

${ }^{23}$ A. Faure, K-Culture Diplomacy: From São Paulo to Tehran, „The Diplomat”, 10.05.2016, https:// thediplomat.com/2016/05/k-culture-diplomacy-from-sao-paulo-to-tehran/ (dostęp: 1.12.2019).
} 
spotkania z przedstawicielami Grupy Wyszehradzkiej (V4) - Czech, Węgier, Polski i Słowacji, Park przygotowała minikoncert z udziałem popularnych grup k-popowych Red Velvet i SHINee. Na zakończenie prezydent wygłosiła przemówienie, mówiąc, że jest wdzięczna za popularność Hallyu zagranicą i za sposób, w jaki łączy ona ludzi pomimo różnych języków i odległości ${ }^{24}$.

Abstrahując od odwołania jej ze stanowiska w 2017 roku w związku ze skandalem politycznym, w przeszłości Park Geun-hye nie była postrzegana jako dobra kandydatka na prezydenta, a koreańska kultura stała się nawet swoistą bronią przeciwko niej. Władze Korei Północnej zamieściły w Internecie parodię piosenki Gangnam Style z udziałem Park Geun-hye, zatytułowaną Yushin Style. Utwór miał na celu krytykę jej poparcia dla dawnego systemu autokratycznych rządów Yushin, ustanowionego przez jej ojca, dyktatora Park Chung-hee ${ }^{25}$.

Obecny prezydent Republiki Korei Moon Jae-in również zdaje sobie sprawę z siły Hallyu, wspiera jej rozwój i wykorzystuje ją do tworzenia przyjaznej atmosfery podczas oficjalnych spotkań na szczeblu międzynarodowym. W listopadzie 2017 roku, kiedy prezydent Stanów Zjednoczonych Donald Trump odwiedził Koreę, członek zespołu k-popowego SHINee towarzyszył jego małżonce, Pierwszej Damie Melanii Trump podczas pobytu. Kiedy Moon Jae-in udał się do Indonezji na spotkanie z prezydentem Joko Widodo, obdarował jego córkę albumem grupy EXO z podpisami członków zespołu, a także nagraniem z udziałem grupy SHINee, w którym muzycy składali jej gratulacje z okazji ślubu ${ }^{26}$. W grudniu 2017 roku miało miejsce istotne wydarzenie pomiędzy Chinami i Koreą Południową - szczyt Partnerstwa Handlowego Korea-Chiny w Pekinie. Koreański prezydent zabrał wówczas ze sobą członków grupy EXO oraz aktorkę Song Hye-kyo jako oficjalnych ambasadorów kultury. Wyróżniającym się zabiegiem koreańskiej dyplomacji publicznej była wizyta prezydenta Republiki Korei w Pyeongyangu w celu rozmów z Najwyższym Przywódcą Korei Północnej Kim Jong-unem. Wtedy to około 40 artystów po raz pierwszy zaprezentowało się na północnokoreańskiej scenie. Podobno Kim specjalnie dopasował swój grafik, aby uczestniczyć w koncercie jako widz i wyraził chęć sprowadzenia swoich artystów do Seulu na podobne wydarzenie ${ }^{27}$. Wreszcie

\footnotetext{
${ }^{24}$ Korea.net, Prague K-pop concert bridges cultural differences, 7.12.2015, http://korea.net/ NewsFocus/Culture/view?articleId=131251 (dostęp: 1.12.2019).

${ }^{25}$ K.J. Kwon, J. Mullen, North Korean Video Evokes „Gangnam Style” to Taunt South Korean Candidate, CNN, 20.09.2012, https://edition.cnn.com/2012/09/20/world/asia/north-koreagangnam-video/index.html (dostęp: 1.12.2019).

${ }^{26}$ Y.C. Kim, Korean President Gifts Autographed EXO Album to the Daughter of Indonesian President, Allkpop, 9.11.2017, https://www.allkpop.com/article/2017/11/korean-president-gifts-autographed-exo-album-to-the-daughter-of-indonesian-president (dostęp: 1.12.2019).

${ }^{27}$ D. Kim, SM Entertainment Supports President Moon Jaein with His Diplomatic Activities, K-pop Love Blog, 4.04.2018, http://kpoplove.koreadaily.com/sm-entertainment-supports-president-moon-jae-in-with-his-diplomatic-activities/ (dostęp: 1.12.2019).
} 
w czerwcu 2019 roku, na spotkanie prezydenta Moon Jae-ina z Donaldem Trumpem, na specjalne życzenie jego córki Ivanki, zaproszono grupę $\mathrm{EXO}^{28}$.

Prezydent Moon ma świadomość siły, jaką posiada Koreańska Fala i umiejętnie wykorzystuje jej potencjał w celu przechylenia szali na korzyść Korei Południowej. Podejmowane przez niego działania w postaci zabierania ze sobą członków grup k-popowych na ważne spotkania na poziomie międzynarodowym mają na celu stworzenie przyjaznej atmosfery i otwartości oraz są rodzajem perswazji.

\section{Koreańska Fala w stosunkach międzynarodowych}

Bez wątpienia Hallyu zmieniło wizerunek Korei, która w przeszłości była postrzegana głównie przez pryzmat wieloletniej okupacji Japonii i napięte stosunki z Koreą Północną. Obecnie jest to kraj demokratyczny, otwarty na stosunki z resztą świata, który przez ostatnie lata poprawił relację z wieloma państwami. Możliwe, że koreańska kultura popularna będzie kluczem do pojednania Korei Północnej i Południowej. Podczas swojej prezydentury Roh Moo-hyun mówił o przyszłym wykorzystaniu Koreańskiej Fali jako narzędzia do zjednoczenia ${ }^{29}$.

W ciągu ostatniej dekady wielu chińskich polityków pozytywnie wypowiadało się na temat Koreańskiej Fali. Przykładowo, prezydent Hu Jintao i premier Wen Jiabao przyznali: „Jeśli chodzi o zjawisko Hallyu, Chińczycy, a zwłaszcza młodzież, są szczególnie zainteresowani, a rząd chiński uważa zjawisko Hallyu za istotny wkład we wzajemną wymianę kulturową między Koreą Południową i Chinami”30. Jednak na przełomie 2016 i 2017 roku Korea napotkała duży problem w promocji na rynku chińskim. Stało się tak z powodu zgody na rozstawienie na koreańskim terytorium amerykańskiego systemu rakiet antybalistycznych (Terminal High Altitude Area Defense, THAAD). Rząd chiński uznał to za możliwe zagrożenie dla bezpieczeństwa swojego kraju, mimo że głównym założeniem THAAD była ochrona przed potencjalnym atakiem ze strony Korei Północnej. Od tego czasu Chiny stopniowo wprowadzały zakaz importu koreańskiej kultury i powiązanych z nią produktów, określając to jako karę dla Republiki Korei i tym samym zawierając przesłanie polityczne. Był to wielki cios, ponieważ Korea jest trzecim największym partnerem handlowym

\footnotetext{
${ }^{28} \mathrm{E}$. Lau, Donald Trump met K-pop boy band Exo and fans give mixed reaction, „The National”, 30.06.2019, https://www.thenational.ae/arts-culture/music/donald-trump-met-k-pop-boy-band-exo-and-fans-give-mixed-reaction-1.881122 (dostęp: 1.12.2019).

${ }^{29}$ S. Kang, „Korean Wave” set to swamp North Korea, academics say, Reuters, 29.04.2011, https:// www.reuters.com/article/us-media-northkorea-idUSTRE73S5J420110429 (dostęp: 1.12.2019).

${ }^{30}$ Prime Minister Wen Fiabao accepts joint interviews with the Korean media, Xinhuanet, 5.04.2007, https://web.archive.org/web/20151223160723/http://news.xinhuanet.com/world/2007-04/05/ content_5940122.htm (dostęp: 1.12.2019).
} 
Chin, a Chiny są największym partnerem handlowym Korei. Sytuacja uległa poprawie dopiero pod koniec 2017 roku, kiedy Chiny zaczęły powoli znosić zakaz ${ }^{31}$.

Zarówno Japonia, jak i Korea Południowa wykorzystują kulturę popularną jako narzędzie soft power. Ze względu na problematyczną przeszłość, głównie z powodu japońskiej okupacji Korei od 1910 do 1945 roku, ich relacje bywają nieprzyjazne. Oba narody walczyły o dominującą pozycję swojej kultury w Azji. Na początku Japonia uważała koreańskie produkty kulturalne za słabą imitację własnych, a Korea utrzymywała zakaz importu kultury japońskiej do lat 90. Rywalizacja o kulturę była odzwierciedleniem ówczesnych stosunków politycznych i społecznych. Zmiana nastąpiła pod koniec lat 90., kiedy koreańskie dramy zaczęły zyskiwać ogromną popularność na rynku japońskim ${ }^{32}$.

Od 2000 roku Hallyu ma także pozytywny wpływ na poprawę nastrojów tajwańskich wobec Korei. Wcześniej Tajwan postrzegał Koreę Południową negatywnie, jednak Koreańska Fala ułatwiła kontakty na szczeblu cywilnym między tymi dwoma krajami i odegrała znaczącą rolę w poprawie stosunków dyplomatycznych. Jak powiedział Dyrektor Ministerstwa Kultury i Turystyki Korei: „Lokalny sentyment do Korei nie był dobry od czasu zerwania stosunków dyplomatycznych, ale Hallyu zasadniczo zmienił lokalne postrzeganie Korei, a wiele osób mówi teraz, że chce wiedzieć więcej o Korei i odwiedzić ten kraj”33.

Co więcej, w maju 2013 roku prezydent Stanów Zjednoczonych Barack Obama, podczas konferencji prasowej z prezydent Park Geun-hye, zwrócił uwagę na to, że Hallyu stopniowo porywa cały świat, a także żartował, że jego córki chciały go nauczyć tańca do Gangnam Style ${ }^{34}$. Fenomen koreańskiej popkultury został poruszony również na spotkaniu Organizacji Narodów Zjednoczonych, kiedy to sekretarz Ban Ki-moon wspomniał o międzynarodowym sukcesie Korei w dziedzinie sztuki, kultury i sportu, które pozostawiają ślady w każdym zakątku świata ${ }^{35}$.

Zjawisko Hallyu wspiera ponadto poprawę stosunków z Afryką Północną i Bliskim Wschodem. Aby lepiej promować się w tych regionach, w 2008 roku utworzono Korea TV (Korea Global Media Group), w nadziei na emocjonalne

\footnotetext{
${ }^{31}$ J.K. Jackson, Future of Hallyu beyond China?, Korea Herald, 1.01.2017, http://www.koreaherald.com/view.php?ud=20170101000168 (dostęp: 1.12.2019).

${ }^{32}$ S. Epstein, $\mathcal{F}$-Pop, K-Pop and transnational reconciliation, [w:] Korean Studies in Shift: PACKS 2010 Proceedings, ed. Ch. Song, Auckland 2011, s. 60-64.

${ }^{33}$ J. Kim, op. cit., s. 31.

${ }^{34}$ Obama White House, Remarks by President Obama and President Park of South Korea in a foint Press Conference, 7.05.2013, https://obamawhitehouse.archives.gov/the-press-office/2013/05/07/remarks-president-obama-and-president-park-south-korea-joint-press-confe (dostęp: 1.12.2019).

${ }^{35}$ United Nations, Addressing National Assembly of Republic of Korea, Secretary-General Expresses Confidence That Country Will Become Stronger Partner of United Nations, 1.11.2012, https://www.un.org/press/en/2012/sgsm14610.doc.htm (dostęp: 1.12.2019).
} 
i kulturowe zbliżenie. $W$ ten sposób udowodniono też równorzędne znaczenie zarówno wymiany kulturalnej, jak i gospodarczej oraz politycznej ${ }^{36}$.

Ciekawe jest to, że Koreańska Fala pomaga nie tylko w sprawach dotyczących kraju, z którego pochodzi. W przyszłości może być ona czynnikiem, który poprawi stosunki między dwoma całkowicie odrębnymi krajami. Na przykład konflikt między Izraelem a Palestyną może zostać złagodzony z powodu zainteresowania tamtejszej młodzieży kulturą koreańską. Jak powiedziała jedna z uczennic z tamtego regionu: „Jest to coś, co daje nadzieję, a w Jerozolimie czasami trudno jest ją znaleźć ${ }^{37}$.

\section{Konkluzje}

Podsumowując, koreańska kultura popularna jest istotnym elementem soft power Korei Południowej i od lat przynosi wiele korzyści. W ciągu ostatniej dekady ewoluowała w globalną sensację, która stopniowo porywa za sobą cały świat. W ciągu dwóch ostatnich dekad przeszła ona wiele zmian. Począwszy od azjatyckiego kryzysu finansowego, rząd południowokoreański zauważył potencjał kultury kraju jako towaru eksportowego do odbudowy gospodarki. Zniesiono cenzurę rozrywki i stworzono prawo wspierania sztuki, na które przeznaczano jeden procent $\mathrm{z}$ budżetu państwa. W tym czasie rząd Korei przeszedł z pośredniego wsparcia sektora kultury na bezpośrednie i zwiększył dotacje. Przełomem stał się światowy sukces utworu Gangnam Style, który miał udział w budowaniu pozytywnego wizerunku kraju. W ostatnich latach jest to kontynuowane m.in. przez grupę EXO.

W sferze politycznej Koreańska Fala znacznie poprawiła sposób, w jaki inne kraje postrzegają Republikę Korei. Możliwość użycia kultury jako soft power została zauważona już w połowie XX wieku przez prezydenta Kima Gu, ale to prezydent Kim Dae-jung po raz pierwszy wspomniał o tym fenomenie w oficjalnym przemówieniu. Rząd koreański zauważył, że równie ważna jest odpowiednia organizacja międzynarodowych wydarzeń, dlatego, na przykład, podczas Zimowych Igrzysk Olimpijskich w 2018 roku w Pyeongchangu sięgnął po pomoc koreańskich gwiazd popkultury. Dodatkowo co roku organizuje on festiwal skupiający fanów k-popu z całego świata. Elementy popkultury były też używane w kampaniach prezydenckich Park Geun-hye i Moon Jae-ina, a także w ciągu ich kadencji. Istotną częścią było organizowanie spotkań na szczeblu międzynarodowym, na których obecne były koreańskie gwiazdy, w celu stworzenia przyjaznej atmosfery. Zarówno politycy, jak i zwykli obywatele

\footnotetext{
${ }^{36}$ The „Asian Wave” hits Saudi Arabia, „Saudi Gazette”, 6.01.2014, https://web.archive.org/ web/20140106181245/http://www.saudigazette.com.sa/index.cfm?method=home.regco\&conten$\mathrm{tID}=2010072579067$ (dostęp: 1.12.2019).

${ }^{37}$ Middle East: Korean pop „brings hope for peace”, BBC, 7.08.2013, https://www.bbc.com/ news/blogs-news-from-elsewhere-23606319 (dostęp: 1.12.2019).
} 
na całym świecie wspominali o Hallyu, będąc pod wrażeniem jego popularności i pozytywnych reakcji, jakie wywołuje. Przejawem soft power Korei Południowej była także poprawa relacji z poszczególnymi krajami.

Jednak pomimo znacznej liczby pozytywnych rezultatów Koreańskiej Fali dla Korei Południowej, nie powinniśmy zapomnieć o pewnych wydarzeniach, które mogłyby osłabić skuteczność soft power. Koreańska popkultura zwróciła się przeciwko prezydent Park Geun-hye, kiedy Korea Północna stworzyła parodię Yushin Style. Również chiński import dóbr kulturalnych z Korei negatywnie wpłynął na państwo, generując spore straty finansowe.

Przyjęta teza, że Koreańska Fala ma pozytywny wpływ na budowanie wizerunku państwa, a rząd koreański zauważył jej siłe i umiejętnie ją wykorzystuje, została więc potwierdzona. Rząd Korei zauważył potencjał Hallyu i próbuje wykorzystać go jako podstawowy element soft power. Jego zastosowanie stale się rozwija i w nadchodzących latach przyniesie jeszcze więcej korzyści i zysków. Inne kraje już próbują czerpać pomysły z udanej polityki Korei, a wkrótce ich kultura może stać się równie, a może nawet jeszcze bardziej ważna. W ciągu najbliższych lat prezydent Moon Jae-in zrobi bez wątpienia jeszcze wiele dla kraju dzięki Koreańskiej Fali. Nie można jednak przewidzieć, czy w przyszłości nie będzie podobnego wydarzenia jak kontrowersyjny THAAD, który tym razem może skutecznie obniżyć status Hallyu jako elementu strategii soft power, a tym samym poważnie zaszkodzić międzynarodowemu wizerunkowi Korei Południowej.

\section{Bibliografia}

The „Asian Wave” hits Saudi Arabia, „Saudi Gazette”, 6.01.2014, https://web.archive.org/ web/20140106181245/http://www.saudigazette.com.sa/index.cfm?method=home. regco\&contentID=2010072579067.regco\&contentID=2010072579067 (dostęp: 1.12.2019).

Belam M., EXO: K-pop boyband thrills Winter Olympics closing ceremony, „The Guardian”, 24.02.2018, https://www.theguardian.com/sport/2018/feb/24/who-are-exo-the-boyband-about-to-thrill-the-winter-olympics-south-korea-k-pop/ (dostęp: 1.12.2019).

Duran N., OPPA GANGNAM STYLE PHENOMENON: Dance Craze, Images, and the Perception of the Philippine Audience, https://www.academia.edu/7590669/OPPA GANGNAM_STYLE_PHENOMENON_Dance_Craze_Images_and_the_Perception_of_the_Philippine_Audience (dostęp: 1.12.2019).

Epstein S., F-Pop, K-Pop and transnational reconciliation, [w:] Korean Studies in Shift: PACKS 2010 Proceedings, ed. Ch. Song, Auckland 2011, s. 57-71.

Faure A., K-Culture Diplomacy: From São Paulo to Tehran, „The Diplomat”, 10.05.2016, https:/thediplomat.com/2016/05/k-culture-diplomacy-from-sao-paulo-to-tehran/ (dostęp: 1.12.2019).

Jackson J.K., Future of Hallyu beyond China?, Korea Herald, 1.01.2017, http://www.koreaherald.com/view.php?ud=20170101000168 (dostęp: 1.12.2019). 
Jin D., New Korean Wave: Transnational Cultural Power in the Age of Social Media, University of Illinois Press 2016.

Kang S., „Korean Wave” set to swamp North Korea, academics say, Reuters, 29.04.2011, https://www.reuters.com/article/us-media-northkorea-idUSTRE73S5J420110429 (dostęp: 1.12.2019).

Kim D., SM Entertainment Supports President Moon Jae-in with His Diplomatic Activities, Kpop Love Blog, 4.04.2019, http://kpoplove.koreadaily.com/sm-entertainment-supports-president-moon-jae-in-with-his-diplomatic-activities/ (dostęp: 1.12.2019).

Kim J., Rethinking Media Flow under Globalisation: Rising Korean Wave and Korean TV and Film Policy since 1980s, Centre for Cultural Policy Studies of University of Warwick, maj 2007.

Kim Koo, https://en.wikipedia.org/wiki/Kim_Koo (dostęp: 1.12.2019).

Kim T., Jin D., Cultural Policy in the Korean Wave: An Analysis of Cultural Diplomacy Embedded in Presidential Speeches, „International Journal of Communication” 2016, Vol. 10, s. 5514-5534.

Kim Y.C., Korean President Gifts Autographed EXO Album to the Daughter of Indonesian President, Allkpop, 9.11.2017, https:/www.allkpop.com/article/2017/11/korean-president-gifts-autographed-exo-album-to-the-daughter-of-indonesian-president (dostęp: 1.12.2019).

Klein E., Posner J., K-pop, Explained, Netflix, USA, 30.05.2018.

Kuwahara Y., The Korean Wave: Korean Popular Culture in Global Context, Palgrave Macmillan 2014.

Kwon K.J., Mullen J., North Korean Video Evokes „Gangnam Style” to Taunt South Korean Candidate, CNN, 20.09.2012, https://edition.cnn.com/2012/09/20/world/asia/northkorea-gangnam-video/index.html (dostęp: 1.12.2019).

Lau E., Donald Trump met K-pop boy band Exo and fans give mixed reaction, „The National", 30.06.2019, https:/www.thenational.ae/arts-culture/music/donald-trump-met-k-pop-boy-band-exo-and-fans-give-mixed-reaction-1.881122 (dostęp: 1.12.2019).

Laurie T.N., Global Glam and Popular Music Style and Spectacle from the 1970s to the 2000s, New York 2016.

Lee S., The Korean Wave: The Seoul of Asia, „The Elon Journal of Undergraduate Research in Communications" 2011, Vol. 2, No. 1, s. 85-93.

Lukmanda R., Popular Culture through Globalization. The Power of Hallyu, Popular Culture through Globalization; The Power of Hallyu, https://www.academia.edu/9339896/Popular_Culture_through_Globalization_The_Power_of_Hallyu (dostęp: 1.12.2019).

Magcamit Y., EXO Becomes First K-Pop Act to Be Awarded Own Commemorative Medals, „Hello Kpop”, 18.04.2018, https://www.hellokpop.com/news/exo-receives-komsco-official-commemorative-medals/ (dostęp: 1.12.2019).

Middle East: Korean pop „brings hope for peace”, BBC, 7.08.2013, https://www.bbc.com/ news/blogs-news-from-elsewhere-23606319 (dostęp: 1.12.2019).

Ministry of Foreign Affairs in South Korea, Foreign Ministry to Host a K-Pop Show as Part of Hallyu Diplomacy, 3.05.2012, https://www.mofa.go.kr/eng/brd/m_5676/view.do?se$\mathrm{q}=311119 \& \operatorname{srchFr}=\& \mathrm{amp} ; \mathrm{srchTo}=\& \mathrm{amp} ; \operatorname{srchWord=\& amp;srchTp=\& amp;multi}$ itm_seq=0\&amp;itm_seq_1=0\&amp;itm_seq_2=0\&amp; company_cd=\&amp;company_nm $=\&$ page $=404 \&$ titleNm $=($ dostęp: 1.12 .2019$)$. 
Nye J.S., Soft Power: The Means to Success in World Politics, New York 2004.

Obama White House, Remarks by President Obama and President Park of South Korea in a foint Press Conference, 7.05.2013, https://obamawhitehouse.archives.gov/the-press-office/2013/05/07/remarks-president-obama-and-president-park-south-korea-joint-press-confe (dostęp: 1.12.2019).

Oh I., Lee H., K-pop in Korea: How the Pop Music Industry is Changing a Post-developmental Society, „Cross-Currents: East Asian History and Culture Review” 2013, No. 9, s. 105-124.

Prague K-pop concert bridges cultural differences, Korea.net, 7.12.2015, http://korea.net/ NewsFocus/Culture/view?articleId=131251 (dostęp: 1.12.2019).

Prime Minister Wen fiabao accepts joint interviews with the Korean media, Xinhuanet, 5.04.2007, https://web.archive.org/web/20151223160723/http://news.xinhuanet. com/world/2007-04/05/content_5940122.htm (dostęp: 1.12.2019).

Shim D., Hybridity and the rise of Korean popular culture in Asia, „Journal of Media, Culture \& Society" 2006, Vol. 28, No. 1, s. 25-44.

United Nations, Addressing National Assembly of Republic of Korea, Secretary-General Expresses Confidence That Country Will Become Stronger Partner of United Nations, 1.11.2012, https://www.un.org/press/en/2012/sgsm14610.doc.htm (dostęp: 1.12.2019).

World Bank, GDP (Current US\$) Korea, Rep, https://data.worldbank.org/indicator/ NY.GDP.MKTP.CD?locations=KR (dostęp: 1.12.2019).

Yonhap News Agency, Full text of Park's inauguration speech, 25.02.2013, https://en.yna. co.kr/view/AEN20130225001500315 (dostęp: 1.12.2019). 